\title{
Effect of Early and Chronic Hypoinsulinism on Adipose Tissue Cellularity in the Rat
}

\author{
R. Goursot, B. Portha, C. Levacher and L. Picon \\ Laboratoire de Physiologie du Développement (Laboratoire associé du CNRS no 307) Université Paris 7, Paris, France
}

\begin{abstract}
Summary. The effect of chronic hypoinsulinism on the development of retroperitoneal adipose tissue was studied in rats injected with streptozotocin at birth. The streptozotocin injection induced an acute neonatal diabetes which regressed spontaneously after one week and led to a chronic state of chemical diabetes in the young and in the adult rat. Growth of chemically diabetic rats was normal although the retroperitoneal adipose tissue showed a relative hypoplasia which appeared at two months and evolved with age so that at 10 months the number of adipose cells in the retroperitoneal adipose tissue was largely decreased with respect to control animals $\left(1.34 \pm 0.12 \times 10^{6}\right.$ versus $\left.2.23 \pm 0.11 \times 10^{6}\right)$. This relative hypoplasia was still present at 20 months. Whereas the hypoplasia associated with the chemical diabetes was highly reproducible, the mean adipocyte size was modified in a variable manner but was never significantly decreased in chemically diabetic rats. These findings indicate that insulin is involved in the control of retroperitoneal adipose tissue cellularity and suggest that the effect of hypoinsulinism on adipocyte number does not depend on a decrease of the mean adipocyte volume.
\end{abstract}

Key words: Chemical diabetes, adipose tissue cellularity, insulin, control of adipocyte differentiation, neonatal rats.

In the various forms of obesity, increased adipose tissue mass is always a result of hypertrophy of the adipose cells. This hypertrophy is associated with hyperplasia as seen in genetic obesity [8] and after pre-weaning overnutrition $[1,10]$, but not in obesity due to damage to hypothalamic ventromedial nuclei [6]. Although the metabolic and endocrine control of lipid accumulation resulting in adipocyte hypertrophy is fairly well documented [15], the endocrine factors involved in the formation and maturation of new fat cells are not well known. Concerning the effect of insulin on adipose tissue cellularity, Salans et al. [22] found that high doses of insulin injected daily into rats from birth to 15 weeks failed to induce any increase of the adipocyte number in the epididymal adipose tissue.

The same result was obtained in adult female rats by Krotkiewski and Björntorp [11]. It is also well known that in some experimental obesities where the plasma insulin levels are very high there is no hyperplasia of the adipose tissue [6]. Although these observations seem to rule out any direct influence of insulin on adipocyte hyperplasia, they do not provide any evidence concerning the possible rôle of circulating insulin in the development of a normal number of adipocytes. Therefore we have studied the effect of an early and long lasting impairment of insulin secretion on adipose tissue cellularity, using a model of chronic chemical diabetes resulting from streptozotocin injection in the newborn rat $[17,18]$.

\section{Material and Methods}

\section{Animals}

Newborn female rats of the Wistar strain received within one day of birth an injection of streptozotocin (Upjohn, Kalamazoo, USA) at a dose of $100 \mu \mathrm{g} / \mathrm{g}$ in $25 \mu \mathrm{l}$ of citrate buffer ( $\mathrm{pH} \mathrm{4.5)}$ by percutaneous injection into the saphenous vein. The control female rats received only citrate buffer. The newborn females were left with their own mothers. The number of animals per litter was kept at eight, since the size of the litter has a short and long term influence on body weight, adipose tissue cellularity and insulinaemia $[10,1,13]$. On day 4 after birth, the streptozotocin-injected neonates were tested for glycosuria with Clinistix (Ames Co-Division Miles Laboratories, Paris, France) and only animals with strongly positive results were kept. They were weaned on day 21 after birth and received pelleted chow (UAR Villemoisson/Orge France: carbohydrate $47 \%$, protein $20 \%$, fat $8 \%$ ) ad libitum.

\section{Samples}

Intravenous glucose tolerance tests were performed in the fed state using animals $1-20$ months old, anaesthetized with sodium pentobarbital ( $4 \mathrm{mg} / 100 \mathrm{~g} \mathrm{IP}$ ). The temperature of the anaesthetized 
rats was checked and maintained at $37^{\circ} \mathrm{C}$ since it has been shown that temperature regulation is impaired during pentobarbital anaesthesia [14] and that a decrease in body temperature results in an impairment of insulin release [3]. Glucose $(0.5 \mathrm{mg} / \mathrm{g}$ body weight) was injected into the saphenous vein and blood samples were obtained from the tail $0,5,15$ and $90 \mathrm{~min}$ after the glucose injection. The blood was immediately centrifuged at $4{ }^{\circ} \mathrm{C} ; 30 \mu \mathrm{l}$ of plasma were used for blood glucose determination and $50 \mu 1$ stored at $-20^{\circ} \mathrm{C}$ for immunoreactive insulin determination. After the IV glucose tolerance test, laparotomy was performed and the pancreas was dissected out, weighed and homogeneized for $1 \mathrm{~min}$ by ultrasonic disintegration at $4^{\circ} \mathrm{C}$ (Sonifier Branson, B12, Heat Systems - Ultrasonics Plainview, USA) in an acid alcohol solution ( $75 \%$ ethanol, $1.5 \% \mathrm{v} / \mathrm{v} 12 \mathrm{~mol} / 1 \mathrm{HCl}, 23.5 \%$ distilled water). The retroperitoneal adipose tissue was also dissected out and weighed.

\section{Assays}

Blood glucose was measured with a glucose analyser (Beckman, Palo Alto, USA). Pancreatic and plasma immunoreactive insulin (IRI) was estimated using purified rat insulin as standard (R 171 Novo, Copenhagen, Denmark), antibody to mixed bovine/porcine insulin and porcine mono-iodinated $\mathbf{I}^{125}$-insulin [4]. Silicate was used to separate free from bound hormone [20]. By this method at least $6 \mu \mathrm{U} / \mathrm{ml}$ can be measured with a within and between assay coefficient of variation of $10 \%$. The average volume and the number of adipocytes per fat pad were determined according to the technique of Sjöström et al. [23] which was slightly modified: the fat pad was cut and examined at three different levels and 500 cells instead of 100 were counted in each fat pad. It is noteworthy that the mean volume of the adipose cells was found to be constant in the sections made at different levels of the same fat pad.

\section{Statistical Analysis}

Results were expressed as mean \pm standard error of the mean ( \pm SEM). The statistical significance of differences between means was evaluated with Student's t test.

\section{Results}

\section{Characteristics of Streptozotocin Diabetes in Newborn Rats}

On day 4 after birth, $85 \%$ of the pups injected with streptozotocin were glycosuric. This neonatal diabetes was spontaneously reversible and glycosuria always disappeared before day 10 . Newborn rats injected with citrate buffer never exhibited glycosuria.

\section{Long-Term Study of Rats with Diabetes Induced at Birth with Streptozotocin}

Body Growth. The weight of the chemically diabetic animals was significantly decreased at day 7 after birth (control rats $14.1 \pm 0.5 \mathrm{~g}$, chemically diabetic rats $11.3 \pm 0.5 \mathrm{~g}, p<0.05$ ). However the difference between body weights of control and chemically diabetic rats was no longer significant at the age of one month. The body length (naso-anal) at 3 months was not different in chemically diabetic (18.9 \pm $0.4 \mathrm{~cm})$ and in control females $(18.5 \pm 0.2 \mathrm{~cm})$.
Blood Glucose, Plasma and Pancreatic IRI. The basal blood glucose level was significantly increased in chemically diabetic rats only at 10 months $(1.46 \pm$ $0.05 \mathrm{~g} / 1$ versus $1.19 \pm 0.06 \mathrm{~g} / \mathrm{l}, p<0.001)$. During the IV glucose tolerance test the glycaemia was significantly increased in 2 month-old chemically diabetic rats $15 \mathrm{~min}$ after glucose injection $(1.75 \pm 0.08$ versus $1.49 \pm 0.06 \mathrm{~g} / \mathrm{l}, p<0.05$ ) and in 5 month-old chemically diabetic rats 15 and $90 \mathrm{~min}$ after glucose injection $(2.47 \pm 0.07$ versus $2.14 \pm 0.09 \mathrm{~g} / 1, p<$ 0.05 and $1.30 \pm 0.05$ versus $1.12 \pm 0.04 \mathrm{~g} / \mathrm{l}, p<$ 0.05 respectively). In chemically diabetic rats, the basal plasma IRI was normal but 5 min after glucose injection, the plasma IRI was significantly decreased at the ages of 1 month $(43.5 \pm 4.4$ versus $85.9 \pm$ $17.1 \mathrm{mU} / 1, p<0.01) 2$ months $(52 \pm 9$ versus $187 \pm$ $52 \mathrm{mU} / 1, p<0.05) 5$ months $(115 \pm 30$ versus 314 $\pm 33 \mathrm{mU} / 1, p<0.01)$ and 10 months $(212 \pm 33$ versus $566 \pm 63 \mathrm{mU} / \mathrm{L}, p<0.01$ ). In 20 -month-old rats the insulin secretion $5 \mathrm{~min}$ after glucose load was sluggish even in the controls and there was no longer any significant difference in plasma IRI between chemically diabetic and control rats $(195 \pm 41$ versus $257 \pm 41 \mathrm{mU} / \mathrm{L} \mathrm{NS}$ ) The IRI content of the pancreas, expressed as $\mathrm{mU} / \mathrm{mg}$ of fresh weight, was always significantly decreased in chemically diabetic rats: $1.60 \pm 0.12$ versus $2.53 \pm 0.16, p<0.01 ; 1.80$ \pm 0.10 versus $2.80 \pm 0.40, p<0.01) ; 1.60 \pm 0.10$ versus $4.50 \pm 0.50, p<0.01$ and $1.80 \pm 0.10$ versus $3.60 \pm 0.20, p<0.01$ at $1,2,10$ and 20 months respectively.

Development of the Retroperitoneal Adipose Tissue (Fig. I). The retroperitoneal adipose tissue gained weight until 20 months in both chemically diabetic and control rats. At 2 months the weight of this tissue was significantly greater in the chemically diabetic rats, but at 5 and 10 months it was significantly less than in controls.

The mean cell volume was significantly greater in 2-month-old chemically diabetic rats $\left(24.8 \pm 3.3 \mu^{3}\right.$ $\times 10^{4}$ versus $14.0 \pm 1.5 \mu^{3} \times 10^{4} p<0.05$ ) but later there was no longer any significant difference in adipose cell size between the two groups.

The cell number increased in two steps in chemically diabetic as well as in control rats. In both groups, after an initial proliferation from birth to 5 months, the adipocyte number remained constant up to 10 months. There was then a further increase until age 20 months (Fig. 1 c). At 1 month the adipocyte number was the same in chemically diabetic and in control rats $\left(0.34 \pm 0.34 \times 10^{6}\right.$ and $0.33 \pm 0.25 \times$ $10^{6}$ ) but at the age of 2 months the number of adipose cells was significantly lower in the chemically diabetic rats $\left(0.91 \pm 0.06 \times 10^{6}\right.$ versus $1.11 \pm 0.08 \times$ $\left.10^{6}, p<0.05\right)$. 


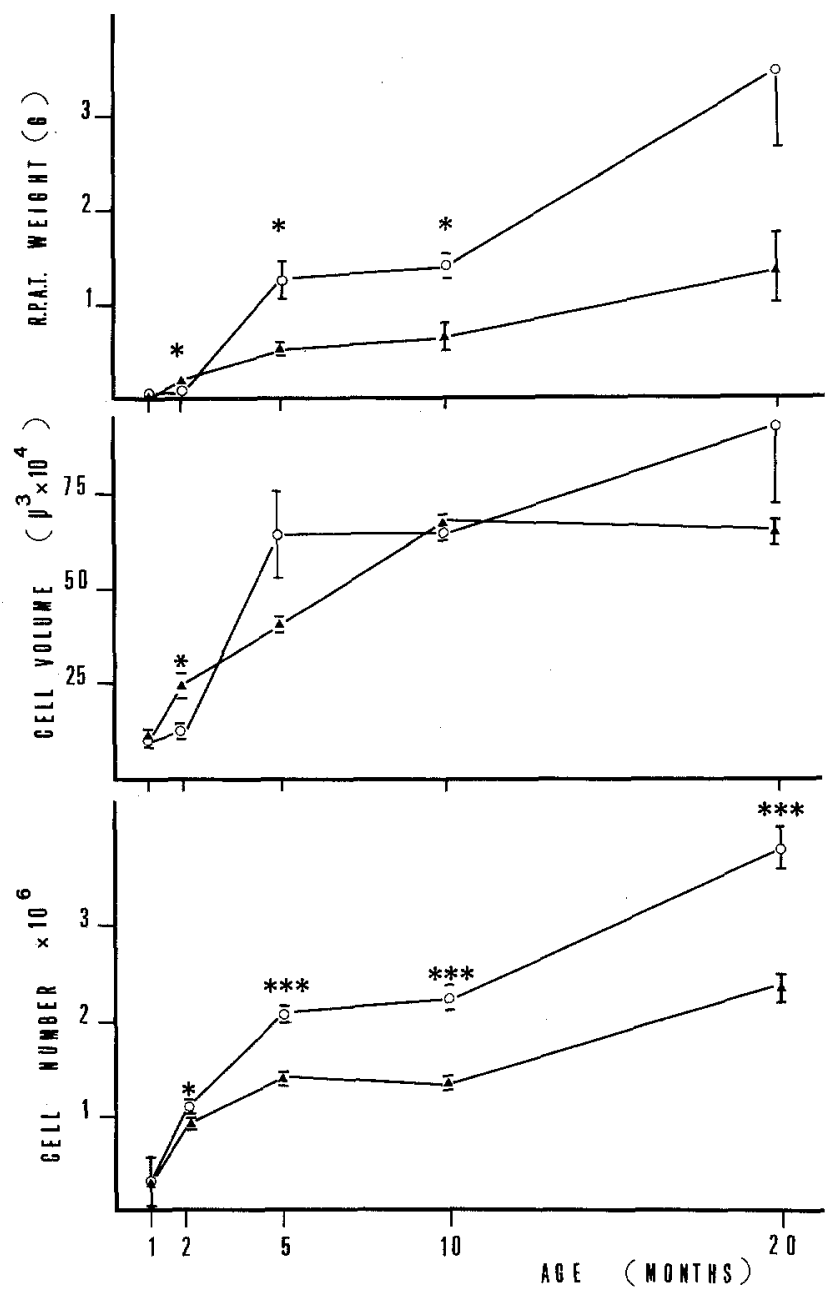

Fig. 1. Weight of retroperitoneal adipose tissue ( $R P A T)$, mean cell volume and cell number in control and chemically diabetic female rats 1-20 months old. Values are expressed as mean \pm SEM. Significance of the difference between control and chemically diabetic rats: $* p<0.05 * * * p 0.001 ; 0=$ control rats; $\boldsymbol{\Lambda}=$ chemically diabetic rats

The difference in cell number between the chemically diabetic and the control rats increased thereafter $\left(1.40 \pm 0.07 \times 10^{6}\right.$ versus $2.10 \pm 0.06 \times 10^{6}$, $p<0.001 ; 1.34 \pm 0.12 \times 10^{6}$ versus $2.23 \pm 0.11 \times$ $10^{6}, p<0.001 ; 2.32 \pm 0.12 \times 10^{6}$ versus $3.83 \pm$ $0.23 \times 10^{6}, p<0.001$ at 5,10 and 20 months respectively). At 20 months the adipocyte number in chemically diabetic rats was only $60 \%$ of that in controls and there was no overlap between the individual values of adipocyte number in chemically diabetic rats $\left(1.92 \times 10^{6}\right.$ to $\left.2.46 \times 10^{6} n=6\right)$ and in control rats $\left(3.42 \times 10^{6}\right.$ to $\left.4.73 \times 10^{6} n=6\right)$.

\section{Discussion}

Body growth of rats injected at birth with streptozotocin was not impaired to a great extent. The slight decrease in weight gain observed in these ani- mals can probably be attributed to the diminution in growth of the adipose tissue, since growth in length was normal.

The salient features of the chemical diabetes induced by streptozotocin at birth - depletion of pancratic stores of insulin and decreased insulin secretion during IV glucose tolerance test - are in good agreement with previous data $[17,18]$. In the present work the effect of hypoinsulinism was studied only in retroperitoneal adipose tissue. It would have been interesting to investigate the adipose tissue at other depots since differences in the response of the adipose tissue from different sites to various parameters such as age, sex, diet and genetic obesity have been documented $[8,12]$. However this type of study would have been difficult to undertake due to the number of rats required and the technique used for counting the adipocytes. Although most studies using only one adipose depot have been done with the epididymal fat pad, we preferred to use the retroperitoneal adipose tissue in view of its long lasting adipocyte proliferation $[12,2]$, and because its cellularity seems particularly responsive to various metabolic and hormonal factors [12]. Furthermore, there is a great variability in mean size and metabolic response to insulin between cells originating from various parts of the epididymal fat pad [21] which we did not find in sections made at different levels of the retroperitoneal adipose tissue.

The main result of our experiments is the clearcut decrease of retroperitoneal adipose tissue cellularity in chemically diabetic rats. This result agrees with those of Hollenberg et al. [7] who showed that in alloxan-diabetic rats the incorporation of ${ }^{3} \mathrm{H}$ thymidine into adipocytes is decreased and that it can be restored to normal by insulin treatment. However, these studies may be criticized on the basis of the recent results of Klyde and Hirsch [9] indicating that it is very difficult in this type of experiment to separate the adipocytes from small cells which incorporate the ${ }^{3} \mathrm{H}$ thymidine and remain closely associated with the adipocytes in spite of the collagenase treatment.

Studies in vitro using cultures of $3 \mathrm{~T} 3$ cells [19] or of preadipocytes originating from human or rat adipose tissue [24] have already shown that insulin is necessary for complete differentiation of the precursor cells into adipocytes. However, we present here the first evidence of an effect of chronic insulinopenia on adipose tissue cellularity in vivo. It is noteworthy that moderate diabetes without permanent hyperglycaemia is sufficient to induce a clearcut effect on adipose tissue cellularity without any significant modification of the cell size. Therefore the diminution of adipocyte number in chemically diabetic rats is not the result of decreased lipid accumulation in 
the cells. A similar lack of correlation between changes in cell number and in cell size has been observed in retroperitoneal adipose tissue from hyperthyroid and control rats [16]. Since the weight growth of the chemically diabetic rats was significantly impaired at 7 days, it might be argued that the reduction of adipose cell number in the retroperitoneal adipose tissue of these rats results not from hypoinsulinaemia but from a decreased caloric intake during a critical period of the development of this tissue. In fact Knittle and Hirsch [10] have shown in rats reared in litters of four or 22 a long lasting effect of early nutrition on adipose tissue cellularity. In these experiments, however, the rats were three times lighter at the time of weaning in the litters of 22 than in the litters of four. Moreover Lemonnier et al. [13] showed that in mice reared in litters of 20 there was, at the age of $4-5$ months, a significant decrease in both adipose cell number and plasma insulin level as compared with mice reared in litters of nine. Taken together with our results, and especially the relatively slight impairment of body growth in chemically diabetic rats, these data suggest that insulinopenia and not decreased caloric intake per se may be responsible for the decreased adipose cell number resulting from early undernutrition.

In conclusion, the present observations strongly suggest that a moderate but long lasting decrease of insulin secretion affects adipose tissue cellularity in the rat.

Acknowledgments. We are indebted to Dr. G. Rosselin (Unité INSERM 55) for the gift of mono-iodinated insulin and to the Upjohn Co., Kalamazoo, Michigan, USA, for the gift of streptozotocin. We wish to thank J. C. Cros and M. F. Kinebanyan for their expert technical assistance. This work was supported in part by the Délégation Générale à la Recherche Scientifique et Technique grant 78-7-03-28 and by the INSERM grant 79-1-483-7.

\section{References}

1. Aubert R, Suquet JP, Lemonnier D (1971) Effects à long terme de trois niveaux d'ingesta lactés sur les lipides corporels, la taille et le nombre de cellules adipeuses de la souris. C R Acad Sci 273: 2636-2638

2. Bertrand HA, Masoro EJ, Yu BP (1978) Increasing adipocyte number as the basis for perirenal depot growth in adult rats. Science 201: 1234-1235

3. Blackard WG, Nelson NC, Labat JA (1967) Insulin secretion in hypothermic dogs. Am J Physiol 212: 1185-1187

4. Freychet P, Roth J, Neville DM Jr (1971) Monoiodoinsulin: demonstration of its biological activity and binding to fat cells and liver membranes. Biochem Biophys Res Commun 43: $400-408$

5. Haller H, Leonhardt W, Hanefeld M (1976) Significance of adipocyte hypertrophy in the pathogenesis of disturbances of carbohydrate and lipid metabolism. Diabetologia 12: 396 A

6. Hirsch J, Han PW (1969) Cellularity of rat adipose tissue: effects of growth, starvation and obesity. J Lipid Res 10: $77-82$
7. Hollenberg CH, Vost A, Patten RL (1970) Regulation of adipose mass: control of fat cell development and lipid content. Rec Progr Horm Res 26: 463-503

8. Johnson PR, Zucker LM, Cruce JAF, Hirsch J (1971) Cellularity of adipose depots in the genetically obese Zucker rat. $\mathrm{J}$ Lipid Res 12: 706-714

9. Klyde BJ, Hirsch J (1979) Isotopic labelling of DNA in adipose tissue: evidence for proliferating cells associated with mature adipocytes. J Lipid Res 20: 691-704

10. Knittle JL, Hirsch J (1968) Effect of early nutrition on the development of rat epididymal fat pads: cellularity and metabolism. J Clin Invest 47: 2091-2098

11. Krotkiewski M, Björntorp P (1976) The effect of progesterone and of insulin administration on regional adipose tissue cellularity in the rat. Acta Physiol Scand 96: 122-127

12. Lemmonier D, Alexiu A (1973) Nutritional genetic and hormonal aspects of adipose tissue cellularity. In: Vague $J$, Boyer J Intern Congress series no. 315. Excerpta Medica, Amsterdam, pp 158-173

13. Lemonnier D, Suquet JP, Aubert R, Rosselin G (1973) Long term effect of mouse neonate food intake on adult body composition, insulin and glucose serum levels. Horm Metab Res 5: 223-224

14. Lomax P (1966) The hypothermic effect of pentobarbital in the rat: sites and mechanism of action. Brain Res 1: 296-302

15. Masoro EJ (1977) Lipids and lipid metabolism. Ann Rev Physiol 39: 301-321

16. Picon L, Levacher C (1979) Thyroid hormones and adipose tissue development. J Physiol [Paris] 75: 539-543

17. Portha B, Levacher C, Picon L, Rosselin G (1974) Diabetogenic action of streptozotocin in the rat during the perinatal period. Diabetes 23: 889-895

18. Portha B, Picon L, Rosselin G (1979) Chemical diabetes in the adult rat as the spontaneous evolution of neonatal diabetes. Diabetologia 17: 371-377

19. Reed BC, Kaufmann SH, Mackall JC, Student AK, Lane MD (1977) Alterations in insulin binding accompanying differentiation of 3T3 L1 adipocytes. Proc Natl Acad Sci USA 74: $4876-4880$

20. Rosselin G, Assan R, Yalow RS, Berson SA (1966) Separation of antibody-bound and unbound peptide hormones labelled with iodine 131 by talcum powder and precipitated silica. Nature 212: 355-357

21: Salans LB, Dougherty JW (1971) The effect of insulin upon glucose metabolism by adipose cells of different size. J Clin Invest 50: 1399-1410

22. Salans LB, Zarnovski MJ, Segal R (1972) Effect of insulin upon the cellular character of rat adipose tissue. J Lipid Res 13: $616-623$

23. Sjöström L, Björntorp P, Vrana J (1971) Microscopic fat cell size measurements of frozen cut adipose tissue in comparison with automatic determination of osmium-fixed fat cells. $J$ Lipid Res 12: 521-530

24. Van RLR, Roncari DAK (1978) Complete differentiation of adipocyte precursors. A culture system for studying the cellular nature of adipose tissue. Cell Tissue Res 195: 317-329

Received: 18 December 1980

and in revised form: 10 April 1981

Professor L. Picon

Laboratoire de Physiologie du Développement

Laboratoire associé du CNRS No. 307

Université Paris VII

2 Place Jussieu

F-75251 Paris Cedex 05, France 